\title{
Power, Getting What You Want, and Happiness: Gorgias 466A4-472D7
}

\author{
Ian J. Campbell
}

Abstract: Interpreters of Socrates' argument at Gorgias 466A4-468E5 that rhetoricians and tyrants have little power because they do almost nothing they want tend either to think that the argument is invalid, or that Socrates relies upon peculiar uses of the terms 'power' and 'want.' By examining this passage within its larger dialectical context, I show that Socrates' argument is valid and relies only on his interlocutor's conventional use of the terms 'power' and 'want.'

\section{Introduction}

Plato's Gorgias enacts Socrates' discussion of the question "what is rhetoric" with the famous rhetorician Gorgias, and, in turn, with Gorgias' followers Polus and Callicles. But with each of his successive interlocutors, Socrates becomes, by degrees, less concerned with eliciting a definition of rhetoric, and more concerned with warning his interlocutors against the unjust manner of living that he takes to follow from the practice of rhetoric. The most dramatic shift in the topic of discussion occurs in Socrates' discussion with the young rhetorician Polus (466A4472D7). In just a few pages, the focus of their exchange — which began as a disagreement about Socrates' account of rhetoric - shifts to such an extent that Socrates can now characterize their disagreement as about the question "who is happy ( $\varepsilon \dot{\delta} \delta \alpha \mu \tilde{\omega} v)$ and who is not" (472D). ${ }^{1}$ This significant transition occurs over the course of a controversial passage in which Socrates argues that rhetoricians and tyrants have exceedingly little power in their cities because they do virtually nothing they want. The purpose of this study will be to examine these surprising claims in their context, so as more accurately to understand Socrates' argument for them.

\footnotetext{
* I would like to thank Hayden Ausland, Hendrik Lorenz, Paul Muench and Matthew Strohl for helpful conversations about and feedback on earlier drafts of this paper.

${ }^{1}$ Socrates characterizes his dispute with Callicles in a similar way, see 500C3-4; 487E8-488A1.
} 
At 466A4 Polus comes to the aid of Gorgias after he has heard Socrates claim that

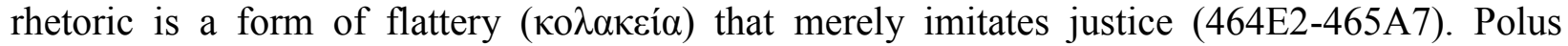
objects, claiming that rhetoricians are clearly not regarded as flatterers (кó $\lambda \alpha \kappa \varepsilon \varsigma)$ : they are, in fact, highly esteemed for their tyrant-like power to kill whomever they want (öv ö $\beta$ ov́ $\lambda \omega v \tau \alpha$ ),

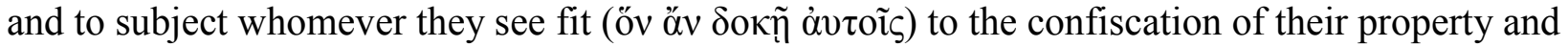
to banishment from their cities (466A4-C2). Socrates claims that Polus is really raising two different points, and distinguishes between them as follows:

$[R]$ hetoricians and tyrants have exceedingly little power in their cities [...] because they do virtually

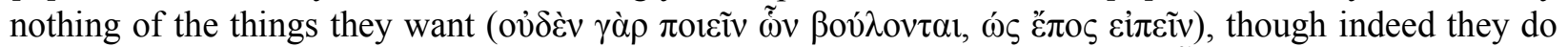

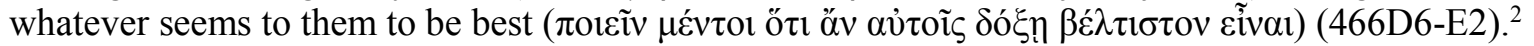

Interpreters of the passage have consistently treated Socrates' ensuing defense of this position as a combination of two separate formulations, 466A4-467A10 and 467B1-468E5, the former being an argument about power, and the latter, one about wanting. Because of the surprising and apparently paradoxical nature of the claims that these arguments defend, they have seemed to many interpreters either to be invalid or to lack a sufficient explanation of certain words that Socrates seems to use in unusual ways. So the scholarly work on this passage has either tried to demonstrate that Socrates' arguments are invalid or tried to explain and defend Socrates' particular uses of the words 'power' and 'want.'

In what follows, I show that Socrates' arguments for these claims are valid, and that his use of the words 'power' and 'want' is completely conventional. I shall do so by considering the larger dialectical context and shall thereby hope to show that the primary mistake of earlier interpreters was to treat the tyrants and rhetoricians passage (466A4-468E5) too much in isolation.

\section{Representative interpretations of Gorgias 466A4-468E5}

What is usually considered the "first formulation" of Socrates" argument (466A4-467A10), which commentators have traditionally understood as an argument about power, is troublesome

${ }^{2}$ All translations are my own. For the Gorgias I have used E.R. Dodds' text (see E.R. Dodds, Plato's Gorgias: A Revised Text with Introduction and Commentary [Gorgias], (Oxford, 1959). For the Euthydemus I have used Burnet's OCT text. 
right from the start because Socrates seems to introduce and rely upon a special sense of the term 'power' as something that is good for its possessor per se. If this is true then Socrates' argument will only be tenable under this restricted use of 'power'; at the conclusion of his argument, he may have said nothing about the kind of power that rhetoricians and tyrants actually have.

A majority of the secondary literature, however, focuses on the second formulation (467B1-468E5) in which Socrates argues for his distinction between 'doing what one wants' and 'doing what seems best to one.' Exactly what Socrates means by this distinction is a matter of some controversy.

Kevin McTighe has argued that Plato is not actually committed to the distinction between these two ideas and that the argument he has Socrates make for it is an intentionally fallacious argument ad hominem which is designed solely to purge Polus of his conceit. ${ }^{3}$ According to McTighe, Socrates equivocates in his use of 'want' in the second formulation and this sophistical equivocation is designed to more effectively persuade Polus. McTighe's Socrates "finds it more efficient to argue fallaciously [...] [than to] strive for logical cogency."4

Heda Segvic takes Socrates' argument for the distinction between 'doing what one wants' and 'doing what seems best to one' to be tenable and interprets the difference between the two as a difference between acting in accordance with one's knowledge ( $\dot{\varepsilon} \imath \tau \tau \eta \dot{\mu} \eta)$ and one's opinion ( $\delta$ ó $\xi \alpha$ ) respectively. ${ }^{5}$ She takes Socrates' use of 'want' in this passage to be a technical one that she calls 'Socratic Wanting':

I (Socratically) want to $\varphi$ only if my wanting to $\varphi$ is linked to my recognition of the goodness of $\varphi$-ing; if it is a mere coincidence that I believe that $\varphi$-ing is the right thing to do and that $\varphi$-ing in fact is the right thing to do, my wanting to $\varphi$ is not Socratic wanting. ${ }^{6}$

Segvic justifies reading the distinction in this way by claiming "the contrast between doxa, opinion, and epistemēe, knowledge, is at the heart of the Gorgias as a whole."7

${ }^{3}$ McTighe, Kevin. "Desire for the Good and the Involuntariness of Wrongdoing: Gorgias 466a-468e" ["Desire"], Phronesis, 29.3 (1984), 193-236 at 226.

${ }^{4}$ Ibid., 226. A similar view is advanced by Roslyn Weiss, see Weiss' reply to McTighe in Weiss, Roslyn. "Ignorance, Involuntariness, and Innocence: A Reply to McTighe," Phronesis, 30.3 (1985), 314-322; see also Weiss, Roslyn. "Killing, Confiscating, and Banishing at Gorgias 466-468" ["Killing"], Ancient Philosophy, 12.2 (1992), 299-315.

${ }^{5}$ Segvic, Heda. "No One Errs Willingly: The Meaning of Socratic Intellectualism" ["Intellectualism"], Oxford Studies in Ancient Philosophy, 19 (2000), 1-40 at 8.

${ }^{6}$ Segvic, "Intellectualism," 11. 
Terry Penner likewise takes the distinction to be tenable, understanding 'doing what one wants' as a matter of getting what one really wants by acting in accordance with a correctly envisaged series of means that ends with one's ultimate desire, and 'doing what seems best to one' as a matter of failing to get what one really wants by acting in accordance with an incorrectly envisaged series that fails of this objective. ${ }^{8}$ For Penner the desired end is, in both cases, "whatever the good really is, even if what it is is different from what we think it is," and the difference between these two notions lies in whether or not one actually reaches one's desired end. ${ }^{9}$

These representative interpretations of Gorgias 466A4-468E5 leave us with the following interpretive options: the first formulation is tenable only if we accept Socrates' seemingly arbitrary qualification that power is something good for its possessor, and the second formulation is either invalid, or depends on a special use of 'want' that Socrates does not define explicitly in the passage. ${ }^{10}$

I take it that, as a general rule of interpretation, it is undesirable to claim that Socrates' argument is intentionally fallacious, provided we are able make sense of it in some other way. In addition, if there is a way of understanding Socrates' argument as tenable without assuming things about Socrates' position that we can find explicitly stated nowhere in the text, this too is to be preferred. The aim of the present study is to show both that Socrates' defense of his position

${ }^{7}$ Segvic, "Intellectualism," 8.

${ }^{8}$ Penner, Terry. "Desire and Power in Socrates: The Argument of Gorgias 466A-468E that Orators and Tyrants Have No Power in the City," ["Desire"], Apeiron, 24.3 (1992), 147-202 at 189. Penner, along with C.J. Rowe, develops the same picture, and tries to show the thesis to be consistent with Meno 77D7E4-which has traditionally been understood, after Santas, to advance the view that desire is for the appaent good - in Penner, Terry and C.J. Rowe. "The Desire for Good: Is the Meno inconsistent with the Gorgias?" ["Meno"], Phronesis, 39.1 (1994), 1-25 at 1-10.

${ }^{9}$ Penner, “Desire,” 195. I have removed Penner's italics. See also Penner and Rowe, “Meno,” 5.

${ }^{10}$ David Wolfsdorf has tried to steer a middle course between the McTighe's and Weiss' ad hominem interpretations of the argument on the one hand, and Penner's and Segvic's alethic-Wolfsdorf's term for a proposition or argument intended by their author to be true or sound-interpretations on the other (see Wolfsdorf, David. "Gorgias 466a4-468e5: Rhetoric's Inadequate Means" ["Rhetoric"], Classical Philology, 103.2 (2008), 109-34 at 112). He calls his interpretation of the argument "dialectic," by which he means an argument that uses premises to which the presenter is not himself committed, but which he uses for the sake of "dialectical expediency." Thus, Socrates' argument is not ad hominem because the premises that he employs represent conventional beliefs that an average interlocutor would hold, but Socrates' argument is not wholly alethic because Socrates is not himself committed to the conventional beliefs that he employs in the argument (see Wolfsdorf, "Rhetoric," 112). 
makes no use of sophistical argumentation of the kind alleged, and that all of the elements necessary for understanding the position that Socrates adopts against Polus are spelled out in the greater dialectical context.

I will defend my view by first offering my own interpretations of the two formulations before turning to what I take to be some key elements that arise in the greater dialectical context. The way that I have divided up Socrates' argument is somewhat unconventional, but the advantage of a reading of the entire section it comprises is that Socrates' full argument will emerge to be not only consistent, but also to contain all of the elements necessary for understanding his position.

2. Rhetoric is not an art: Socrates' account of rhetoric and the "first formulation" of Socrates' argument (464B2-467A10).

In this section I discuss what is traditionally called the first formulation of Socrates' argument (466A4-467A10). To do so, I think we first need to consider briefly the passage that immediately precedes the first formulation, in which Socrates describes the difference between

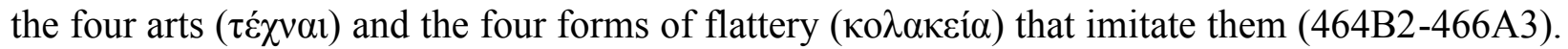
This passage has been largely passed over in discussions of the subsequent section on tyrants and rhetoricians (466A4-468E5). However, I take the opposition between justice and rhetoric that Socrates sets forth in this earlier passage to be the basis of the position that he later adopts against Polus. Having first outlined this important opposition, I will then discuss the first formulation, and its apparent problems, which I take to disappear when considered in light of the preceding context.

Socrates says of the four arts (legislation, justice, gymnastics and medicine): "some take care of the body [gymnastics and medicine] and others take care of the soul [legislation and justice], always with a view to what is best" (464C4-5). But of flattery, Socrates says

$[\mathrm{H}]$ aving distributed itself into four parts, and having clothed itself with each of these parts [sophistry with legislation, rhetoric with justice, cosmetics with gymnastics, cookery with medicine] it pretends to be that which it has donned, and it thinks nothing of what is best, and always hunts and deceives ignorance by means of what is pleasant, so that it seems to be of greatest value (464C6-D3). 
In a later statement directed at Polus, Socrates claims that he refuses to call rhetoric an art because it "has no rational account ( $\lambda$ ó yov) of the nature of the one to whom it administers ( $\pi \rho \circ \sigma \varphi \varepsilon ́ \rho \varepsilon \imath)$ or of the things it administers" (465A3-4). ${ }^{11}$ E.R. Dodds, who is careful to notice the medical metaphor in Socrates' use of $\pi \rho о \sigma \varphi \varepsilon ́ \rho \varepsilon 1$, paraphrases this as a claim that rhetoric "has no rational understanding of the patient or the prescription." 12 On this reading, the difference between justice and rhetoric, according to Socrates, is that justice is able to give an account of the nature of what is best (i.e., the general 'prescription' of these four crafts - see 464C4ff.) and of that to which it administers this treatment, the soul (see 464B3-8; 464C6-D3). Rhetoric, on the other hand, thinks nothing of what is best for the soul, but, because it is pleasing, it nevertheless seems to be of great value to those who give no thought to justice.

The first formulation follows directly on the above-mentioned passage. It begins when

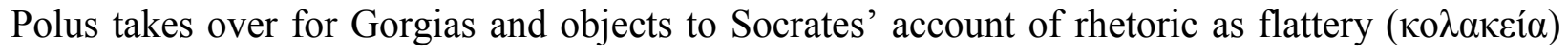
on the grounds that rhetoricians are not regarded as flatterers (Кó $\lambda \alpha \kappa \varepsilon \varsigma)$. He argues instead that rhetoricians are regarded as having exceedingly great power in the city, because they, like tyrants, are able to kill whomever they want (öv ö $\beta$ ov $\lambda \omega v \tau \alpha \imath$ ), and to subject whomever they see fit (őv ớv cities (466A9-10; 466B4-5; 466B11-C2). Socrates, on the other hand, takes up the position that rhetoricians have exceedingly little power in the city-if, that is, by 'power' Polus means something that is good for the one who has it (466B6-7):

$[R]$ hetoricians and tyrants have exceedingly little power in their cities [...] because they do virtually

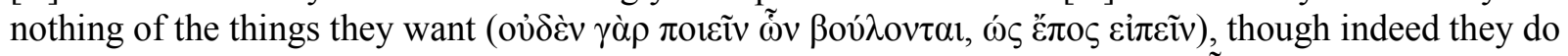

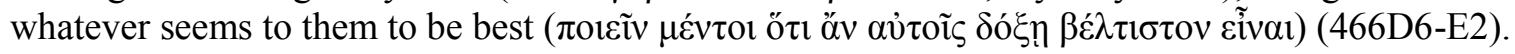

Polus' initial objection to this position has occasioned a number of interpretive difficulties. Polus cannot see why tyrants' and rhetoricians' ability to do whatever seems best to them is not evidence that they have the great power he has ascribed to them (466E3). Polus' working assumption in this objection seems to be the following:

(P) The ability to do whatever seems best to one is sufficient for having great power.

${ }^{11}$ I accept Dodds' emendation of the text (see Dodds, Gorgias, 94; 229-30).

${ }^{12}$ Dodds, Gorgias, 229. 
Socrates undermines Polus' objection with the following argument:

(1) Great power is something good for the one who has it (466E6-8).

(2) It would not be good for one to do whatever seems best to one (which, on Polus' view, is to exercise one's power) without intelligence (voṽ $\mu$ ì ह̌ $\chi \omega v)$ (466E9-12).

(3) Therefore, unless Polus can show that rhetoricians have intelligence, they do not have great power (466E13-467A6).

Socrates thus responds to Polus' objection by showing him that, given his own conception of power as something unqualifiedly good for its possessor, he cannot assume that rhetoricians' ability to do whatever seems best to them is sufficient for their having great power. If Polus is to show that rhetoricians have power, he must "demonstrate that rhetoricians have intelligence

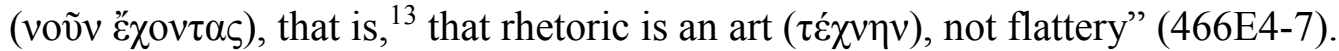

There are potentially two problems with Socrates' argument. First, his initial identification of power as something unqualifiedly good in (1), seems to be a serious weakness if he is introducing a special meaning of 'power.' As Penner has noticed, if Socrates introduces and relies upon a technical usage of 'power' his argument would only be valid for that meaning (sc. 'Socratic power'), so that, even when he is finished responding to the Polus' objection, rhetoricians and tyrants might still have power in some more ordinary sense of the word. ${ }^{14}$ It is not, however, necessary to understand this view of power as a technical usage that Socrates introduces to trick Polus. Noticeable in this connection is Plato's care in having Socrates attribute this view of power to Polus:

[Soc] [T] hey don't have power if you say power is something good for the one who has it (466B6-7). | [Pol] [I] s this [sc. doing what seems best to one] not having great power? | [Soc] No, at least not as Polus says. | [Pol] I say it isn't? I certainly say it is! | [Soc] By the---! you don't, since you say that power is good for the one who has it (466E3-7).

Rather than arbitrarily restricting his use of 'power,' Socrates is gaining Polus' assent to one premise by appealing to Polus' own somewhat unreflective, conventional belief that power is something good per se. The argument that Socrates proceeds to make against Polus' objection

${ }^{13}$ I read the kai epexegetically: Socrates claimed earlier that rhetoric is not an art because it cannot give a rational account ( $\lambda$ ó $\gamma$ ov) of the things it applies or of the one to whom it applies them. On this reading, the present claim simply reinforces this earlier point: Socrates will not consider rhetoric an art unless Polus can show that rhetoricians in fact have the knowledge that an art requires.

${ }^{14}$ Penner, 149. 
does not employ technical notions to trick Polus: it is designed precisely to show that tyrants and rhetoricians don't have the power that Polus attributes to them. ${ }^{15}$

Secondly, a question might arise regarding Socrates' claim in (2) that doing whatever seems best to one-which on Polus' view is equivalent to exercising one's power-is not good for someone who lacks intelligence. In the Gorgias we get no explicit argument for this claim. It is, however, a familiar position that Plato has Socrates adopt and defend at length in other dialogues. Based on such parallels considered against the larger context in the Gorgias, I suggest that we may reasonably infer that the same sort of view is at work here. Perhaps the clearest example of such an argument is Euthydemus 278E3-282D3, where Socrates demonstrates for the sophists Euthydemus and Dionysodorus how he supposes they ought to "exhort the young man [sc. Clinias] to cultivate wisdom and virtue" (278D1-3). ${ }^{16}$ The second argument (280B1-281B4), which shows that wisdom is necessary for the correct and successful use of good things, runs as follows:

(1) If we have good things (enumerated earlier at 279A8-B5 as bodily goods: health, beauty and other bodily needs; external goods: noble birth, power and honor; and psychic goods: self-control, justice, and

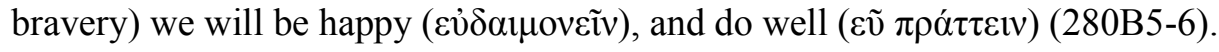

(2) These things are only good if they benefit us (280B7-8).

(3) The mere possession of these good things does not make them beneficial, it is necessary to actually use them (280B8-E3).

(4) However, the mere use of a good thing is not sufficient for it to be conducive to happiness; it has to be used rightly, because there is more harm done if someone uses a thing incorrectly than if they leave it alone (280E3-281A1; for more on the claim about harm see 281B4-D2).

(5) It is knowledge that directs our conduct in relation to the right use of these things (281A1-281B4).

${ }^{15}$ Gregory Vlastos has argued that, while Socrates and Polus agree that rhetoricians have power in some ordinary sense of the term (i.e., that they have the power to kill, confiscate, and banish), in this first stage of argumentation Socrates shows that they do not have 'great power,' which Vlastos construes as power in the hands of a rational agent, acting rationally (see Vlastos, Gregory. "Does Socrates Cheat?" in G. Vlastos, Socrates: Ironist and Moral Philosopher, (Cornell, 1991), 132-156 at 148-9). For Vlastos, Socrates' argument against Polus' objection shows only that rhetoricians and tyrants do not have 'great power.' I think that this misconstrues Socrates' use of the term 'great power.' The term is used in this argument because this is the kind of power that Polus thinks tyrants and rhetoricians have, not because Socrates is trying to distinguish two distinct kinds of power. Polus and Socrates both refer to the power of tyrants and rhetoricians as 'great' because these men are conventionally regarded as having the greatest power of anyone in their cities (see 466B4-5). The distinction is not between two kinds of power, but between degrees.

${ }^{16}$ Socrates advances a similar view at Apology 30B2-4 and Meno 77B2-78B6. 
(6) Knowledge is therefore necessary for the things conventionally understood to be good to actually be good and conducive to happiness (281D2-E5).

I understand Socrates' claim in the Gorgias that it would not be good for an unintelligent person to do whatever seems best as analogous to these claims he makes about various goods in the Euthydemus. According to both of these views, knowledge is required for the correct and successful use of things conventionally understood as good per se, and the Euthydemus argument represents a more pleonastic line of reasoning that Socrates might have presented had Polus not agreed to the premise in question strait away.

Socrates' position in the Gorgias is that rhetoricians have no rational understanding ( $\lambda$ ó $o v$ ) of what is best ('the prescription') for the soul ('the patient') (465A3-4). And in this first stage of argumentation Socrates has shown that — unless Polus can "demonstrate that rhetoricians

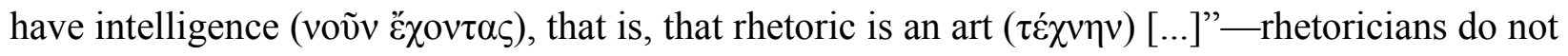
have the rational understanding necessary for their doing what seems best to them to be beneficial (466E4-7). Socrates' argument against of Polus' assumption (P) is simply a reinforcement of the position that he has already taken against rhetoric as a form of flattery in an earlier passage (464B2-466A3). Polus assumed that being able to do what seems best to one was sufficient for having great power, but Socrates' argument has shown him that rhetoricians who do what seems best to them, in so doing, do not actually exercise power that is good for the one who has it.

There does not, therefore, seem to be anything problematic in Socrates' appeal to the idea that knowledge is required for doing what seems best to one (i.e., on Polus' view, exercising one's power) to be beneficial (i.e., to count as power that is good for the one who has it). We can reasonably infer that Socrates has in mind something like this familiar view that knowledge, or intelligence, ${ }^{17}$ is necessary for the correct and successful use of good things. But rather than simply showing that the rhetorician's use of power does not turn out well, in this context the argument shows that rhetoricians have no power at all, because Polus insists that power is

${ }^{17}$ In this section of the Gorgias, the key notion constituting an art ( $\left.\tau \dot{\varepsilon} \chi \nu \eta\right)$ is not $\dot{\varepsilon} \pi \imath \tau \eta \dot{\mu} \mu$, as Segvic has argued (see Segvic, "Intellectualism," 8). Rather, Socrates qualifies art as something that "thinks of what

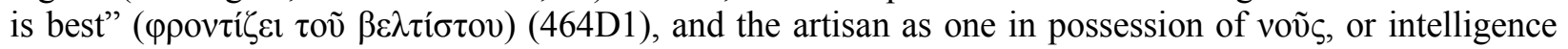
(466E13). I still think, despite the difference in terminology, that the Euthydemus passage helps to clarify the sort of argument that Socrates might have made, had Polus pressed his claim in premise (2) that it would not be good for one to do what seems best without intelligence. 
something that is unconditionally good for the one who has it. It may appear that rhetoricians are exercising power when they submit whomever they see fit to the confiscation of property and to banishment from their cities, but this is not in fact power because rhetoric is not an art. Rhetoricians who do whatever seems best to them do not have power - as Polus understands itbecause they do not possess the intelligence necessary for their doing what seems best to them to count as power that is good for the one who has it.

After Socrates has defeated Polus' objection, he transitions into a discussion about wanting. So far I have gone along with the traditional division of Socrates' defense of his position into two distinct arguments, but I would now like to challenge this view and explain how I prefer to characterize the relationship between these two stages of argumentation.

The transition from 466A4-467A10 to 467B1-466E5 has, at least since Olympiodorus' sixth-century commentary on the Gorgias, ${ }^{18}$ been regarded as a major break in the dialogue, namely, a transition from an argument about power to an argument about wanting. But it does not seem to me that this is the best way to understand this transition because 466A4-467A10 the so-called "first formulation"-is not a complete argument for Socrates' stated position. At this point, Socrates has only answered Polus' objection by showing that doing what seems best to one is not in fact sufficient for having great power. But he has provided no argument for his primary claim that rhetoricians and tyrants have exceedingly little power in their cities because they do nothing they want (466D6-E2). Thus, after he answers Polus' objection, Socrates immediately transitions into a defense of his primary reason for thinking that rhetoricians and tyrants have little power:

[Soc] Then will you demonstrate that rhetoricians have intelligence, that is, that rhetoric is an art and not flattery, having refuted me? If you leave me unrefuted, rhetoricians and tyrants doing in their cities what seem best to them will have acquired no good thereby. Power is, as you say, a good thing, and even you agree that to do what seems best without intelligence is bad, do you not? | [Pol] I do. | [Soc] How then could rhetoricians or tyrants have great power in their cities if Socrates is not refuted by Polus that they do the things they want" (466E13-467A10)?

Penner has interpreted this transition differently than I have. For Penner, the fact that Socrates suddenly steers the conversation towards a discussion of wanting indicates Socrates'

18 In Olympiodorus' In Platonis Gorgiam Commentaria, lecture 15 covers 466A4-476C4, Lecture 16 covers 467C5-468E5. See Olympiodorus, Commenary on Plato's Gorgias, trans. R. Jackson, K. Lycos, and H. Tarrant (Leiden, 1998). 
own dissatisfaction with the first formulation of the argument. ${ }^{19}$ This apparently superfluous dialectical move, argues Penner, is supposed to alert us to the fact that Socrates does not think he has won the argument with this first formulation, and that he needs to reformulate the argument in terms of wanting. ${ }^{20}$

However, it seems to me that Penner's interpretation does not satisfactorily establish that the passage should be understood as the first formulation of an argument that is later reformulated. Socrates' position is that tyrants and rhetoricians have the least power in their cities because they do nothing they want, even though they do what seems best to them (466D6E2). Polus objected that the latter concession - that they do what seems best - was sufficient for rhetoricians and tyrants to have power. Socrates then answered this objection by placing the burden of proof on Polus to show that tyrants and rhetoricians have the knowledge necessary for their doing what seems best to count as power that is good for the one who has it. Now that Socrates has dealt with this objection, he takes up a defense of his primary claim: that rhetoricians and tyrants have the least power in their cities because they do almost nothing they want.

\section{Socrates' argument for a distinction between 'doing what one wants' and 'doing what seems} best to one' (467B1-466E5)

In this section, I shall defend Socrates' argument for a distinction between 'doing what one wants' and 'doing what seems best to one' against McTighe's charge of equivocation, and I shall attempt to demonstrate that the mistake that both Segvic and Penner make is to conclude their interpretations of Socrates' argument while it is still incomplete.

As the result of a brief and highly dramatic exchange in which Polus expresses his disbelief that Socrates is earnest about his claim that 'doing what one wants' and 'doing what seems best to one' are not the same thing (467B1-C4), Socrates begins a defense of his claim that rhetoricians and tyrants do virtually nothing they want by first defending the distinction he drew between these ideas. The following summarizes Socrates' argument for this distinction:

\footnotetext{
${ }^{19}$ Penner, "Desire," 169.

${ }^{20}$ Ibid., 169.
} 
(1) Whenever we act it is for sake of something ${ }^{21}$ (e.g., we take medicine for the sake of health, or sail for the sake of wealth) and we don't want the thing we're doing, but the thing for the sake of which we do it (467C5-467E1).

(2) All things are either good (e.g., wisdom, health, and wealth), or bad (e.g., ignorance, sickness, and poverty), or in between these things ( $\mu \varepsilon \tau \alpha \xi \grave{v} \tau o v i \omega v$-henceforth: "intermediate things"), things which sometimes partake in what is good, sometimes in what is bad, and other times in neither (e.g., sitting, walking, running, sailing, sticks, and stones) (467E1-468A4).

(3) When we do intermediate things, we do them for the sake of good things (468A5-B4).

(4) Killing, confiscating and banishing are intermediate things: when we do them, we do them because we suppose that they will be better for us (468B4-6).

(5) We don't want to kill, confiscate and banish unqualifiedly ( $\dot{\alpha} \pi \hat{\omega} \tilde{\varsigma}$ öv $\omega \varsigma)$; we only want to do these things if doing so is beneficial, and if they are harmful we do not want to do them (468C2-8) (from (3) and (4)).

(6) So, if one kills, confiscates or banishes, supposing that doing these things will be better when in fact they turn out worse, one is doing what seems best to one, and not what one wants (468D1-7) (from (5)).

(7) If power is something good, then such a person (described in (6)) does not have great power in his city (468D7-E3).

(8) Therefore, it is possible for one who does what seems best to one not to have great power nor to do the things one wants (468E3-5) (from (6) and (7)).

Questions most prominently entertained about this passage concern Socrates' use of 'want.' Interpreters tend to take his use of the word to be either inconsistent, or at least peculiar to this passage.

Kevin McTighe finds a logical inconsistency in the argument on the grounds that Socrates allegedly equivocates in his use of 'want.' Socrates wins Polus' approval of his threefold division in (2) with health and wealth as his examples of good things, examples that Socrates, in other dialogues, claims are not actually good per $s e .{ }^{22}$ Because of this, McTighe has argued that when Socrates argues in (3) through (5) that we want good things, he is using 'want' de dicto, i.e., employing a usage that fixes the content of the desire the way that the agent

${ }^{21}$ It is important for the view I develop further below that Socrates is not here making a claim about

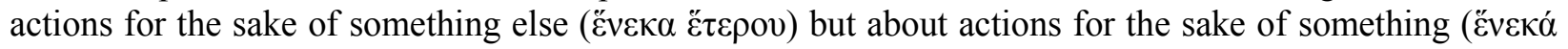
$\tau \mathrm{ov}$ - see 467D7). The present statement does not commit Socrates to the claim that all actions are for the sake of something separate from the action itself. This statement only commits him to the claim that all actions are goal-directed. This leaves open the possibility that the thing for the sake of which an action is performed is internal to the action itself (i.e., performing an action might amount to a fragment of happiness; the action itself might be what happiness amounts to here and now).

${ }^{22}$ As an example of a passage in which Socrates denies that health and wealth are good on their own, McTighe cites Euthydemus 278E-281E, (see part 2 above and McTighe, "Desire," 220). 
would. ${ }^{23}$ McTighe argues further that when Socrates asks Polus in (6) whether tyrants want to kill, confiscate and banish if these actions indeed turn out badly, he is fixing the content of the desire objectively, that is, he is using 'want' de re. ${ }^{24}$

It is important to notice, however, that Socrates introduces the pertinent statement by advancing it as Polus' view: "don't you say that wisdom, health, and wealth are good" (467E45)? As he did in reference to power earlier (see 466B6-7 \& 466E3-7), Socrates appeals to conventionally recognized goods in order to win the approval of his interlocutor, except here he does not go on to qualify these goods as he did before with power. But here, the division of goods in (2) is established before Socrates even makes the distinction that we do intermediate things for the sake of the good things we want in (3); after this, health and wealth are never mentioned as objective goods according to the modified scheme. There is then no need for us to interpret Socrates' use of 'want' in (3) through (5) de dicto. ${ }^{25}$ McTighe's interpretation based on an inconsistent use of 'want' is therefore unnecessary. ${ }^{26}$ Not only is there nothing in the text that

${ }^{23}$ McTighe, "Desire," 206; 220.

${ }^{24}$ Ibid., 206.

${ }^{25}$ For Wolfsdorf, Socrates intends (2) de re, that is, when Socrates tries to establish the threefold division of all things, he treats health and wealth as though they were real goods (Wolfsdorf, "Rhetoric," 129). This reading fails to capture the care with which Socrates distances himself from this view in attributing it to Polus. As Socrates did in the first stage of argumentation with respect to Polus' conception of great power (see 466B6-E8), here Socrates appeals to his interlocutor's conventional beliefs. The care with which he distances himself from the view suggests that, in both cases, Socrates speaks de dicto when he calls power, health, and wealth goods per se.

${ }^{26}$ Roslyn Weiss, like McTighe, also thinks that this alleged equivocation is a reason for taking the argument to be invalid. While she takes the "first formulation" of the argument to be valid (see Weiss, "Killing," 301-303), she argues that, in the second formulation, Socrates initially appeals to conventional goods as the objects of desire, but by the end of the argument, he is arguing that we only want what is truly good (see Weiss, "Killing," 303-309). With respect to McTighe's argument, I have shown why this is an unnecessary assumption; her analysis of the argument as a fallacious ad hominem is therefore inadequate for analogous reasons. In addition to positing an inconsistency in his use of 'want,' Weiss also contends that Socrates does not actually think that killing, confiscating and banishing are intermediate actions, using as evidence of this the fact that Socrates claims later in the dialogue that the person who puts someone to death, justly or unjustly, is unenviable (see 468E6-469B2 and Weiss, "Killing," 309310). But this isn't quite what Socrates says. It is true that when Polus claims that a person killing, confiscating, or banishing ought to be envied regardless of whether or not these actions are performed justly or unjustly, Socrates silences him on grounds that "one ought not envy the unenviable, or the miserable, but pity them" (469A4-5). However, Socrates goes on to carefully distinguish between doing these things justly and unjustly twice: "[Pol] So, you think that a person who puts to death anyone he sees fit, and does so justly is miserable and to be pitied? | [Soc] No, I don't, but I don't think he's to be envied either. | [Pol] Weren't you just saying that he's miserable? | [Soc] Yes, the one who puts someone to death unjustly is, my friend, and he's to be pitied besides. But the one who does so justly isn't to be envied" 
requires us to understand Socrates' use of 'want' in this way, but it can be shown that what Socrates does mean by 'want' is made clear by the subsequent context.

At this point in the text, Socrates has shown that 'doing what seems best to one' is not sufficient for having great power (466E3-467A10), and he has argued for a distinction between 'doing what one wants' and 'doing what seems best to one' (467B1-468E5). He has not, however, provided a complete defense of his own stated position (i.e., that tyrants and rhetoricians have little power because they do not do what they want). By 468E5 he has only shown that it is possible for someone doing what seems best to one to not be doing what one wants in case the intermediate things one does for the sake of good things turn out badly. Socrates still has yet to tell us what the good thing is for the sake of which tyrants and rhetoricians kill, confiscate, and banish. And he still has yet to say why he thinks that rhetoricians and tyrants fail to attain this end for the sake of which they do these things. In other words, at 468E5, Socrates has not yet concluded his argument for his claim that tyrants and rhetoricians have the least power in their cities because they do virtually nothing they want.

To preface briefly the criticism I develop more fully below, we can already see that Segvic and Penner (who only address 466A4-468E5) both construe Socrates' use of 'want' in a way that is not explicitly attested in the text. Pace Segvic, Socrates has nowhere explicitly connected the notions of 'doing what seems best to one' and 'doing what one wants' with those of acting in accordance with $\delta$ ó $\xi \alpha$ and $\dot{\varepsilon} \pi \iota \tau \eta \dot{\mu \eta}$ respectively. And Pace Penner, neither do we have any good reason to think that, in each case, 'doing what one wants' amounts to acting in accordance with a correctly envisaged scheme of means that ultimately leads to what one (actually) wants. Rather than categorically endorsing an instrumentalist account of desire, all that Socrates' argument has so far established is that one does not do what one wants if the intermediate actions one undertakes fail to achieve the good ends for which they were undertaken. And this fact, rather than amounting to a complete elucidation of 'doing what one wants,' simply establishes a distinction, in one type of case (i.e., intermediate actions), between the two notions that Polus thought identical (see 467B1-C4). I find both Segvic's and Penner's interpretations unsatisfying, moreover, since it is possible to show, on the basis of the full

(469A9-B2). It is therefore also unnecessary for us to posit an inconsistency in Socrates' conception of killing, confiscating and banishing. All that Socrates claims in this later passage is that a person justly performing such actions is not the sort of person of whom one ought to be envious, a claim perfectly consistent with a conception of these actions as intermediate. 
argument of which the section just concluded is but one stage, that Socrates and Polus employ the same, completely conventional usage of 'want.' Both commentators thus neglect exegetical resources in the larger dialectical context that might allow them to construe Socrates' use of 'want' in such a way that would not require them to posit peculiar uses of the word that are not explicitly attested in the text.

\section{Getting what you want and happiness (468E6-472D7)}

In this section I show how the questions that remain unanswered at (what is traditionally considered to be) the conclusion of Socrates' argument are answered in the subsequent dialectical context. The exchange that immediately follows on the conclusion of Socrates' argument (468E6-470A8) is a digression from his defense of his stated position because in this exchange he responds to Polus' objection ad hominem: "As if you [sc. Socrates] would not want to be able to do what seems [sc. best] to you in your city rather than not" (468E6-7). A full treatment of the discussion that results from Polus' objection is beyond the scope of this paper; for the present purpose it is enough to show how Socrates steers this digression back to a direct discussion of his position. For Socrates to properly answer this objection he has to first get clear about what Polus means by 'tyrant' (469C4). Polus says he takes 'being a tyrant' to be equivalent to being in a position to do whatever one sees fit (ö ớ $\delta$ gets him to add the further qualification 'without being punished' (469C5-7; 469C8-470A8). In making such claims Socrates informs Polus that he has simply returned to his initial objection to Socrates' position (namely (P)), and thereby turns the discussion back to the topic at hand:

O surprising fellow, again it seems to you that if acting beneficially is in keeping with doing what seems [sc. best], it is good, and this, as it seems, is having great power; and if not, it is bad and having little power (470A9-12).

Socrates proceeds to ask Polus when he thinks that it is better to kill, banish, and confiscate - that is, when these activities are beneficial-but Polus refuses and has Socrates answer (470B1-11). It is at this point that Socrates finally reveals what he means by his claim that the killing, confiscating, and banishing of tyrants and rhetoricians are not in fact evidence of great power the way Polus assumes they are. Socrates' answer is that when someone does these things justly it is better, and when unjustly, it is worse (470C1-3). 
This claim is to be understood closely together with Socrates' claims about justice and rhetoric that precede the passage on tyrants and rhetoricians. As an art, justice aims at what is best for the soul (464C3-5). Actions performed justly will be therefore beneficial because justice aims at what is best. Rhetoric, on the other hand, "gives no consideration to what is best," and therefore has no understanding of what is beneficial for the soul (464D1-3). Socrates therefore thinks that rhetoricians do virtually nothing they want because he holds that they lack the expert ( $\tau \varepsilon \chi \nu 1 \kappa o ́ \varsigma)$ attention to what is beneficial for the soul.

But a question now arises. Just what is this benefit that rhetoricians and tyrants want but fail to get and that practitioners of justice secure? Socrates' earlier claim that rhetoric gives no thought to what is best for the soul already suggests an answer, but the drama of the dialogue actually proceeds to reveal what both Socrates and Polus think it is through Polus' attempted refutation of Socrates' above-mentioned claim:

Surely, Socrates, it is not necessary to refute you by means of ancient matters. For things that happened yesterday and the day before are sufficient to refute you, and to prove that many people performing

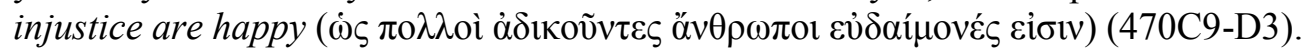

Polus challenges Socrates' claim (that killing, confiscating, and banishing are only beneficial when they are performed justly) by objecting that many who perform injustice are happy. The fact that Polus frames his objection in terms of happiness suggests that he understands this to be the benefit for the sake of which tyrants and rhetoricians perform their intermediate actions of killing, confiscating, and banishing.

Socrates takes no issue with Polus' understanding 'want' in this way. As he takes on Polus' criticism, he does not deny that happiness is the desired end in performing these actions; what he disputes is that these men actually become happy by doing such things unjustly. Socrates provides the following lucid analysis of their primary point of dispute in concluding his reply (471E4-472D4) to Polus' speech in praise of the unjust tyrant Archelaus (471A4-D2):

[T] he things about which we dispute are not small matters at all, but these things are just about the finest things about which to know, and the most shameful not to know; for the sum of the matter of these things is to know or not to know who is happy ( $\varepsilon \dot{\delta} \delta \alpha \mu \tilde{\omega} v)$ and who is not. [...] [Y]ou believe that it is possible

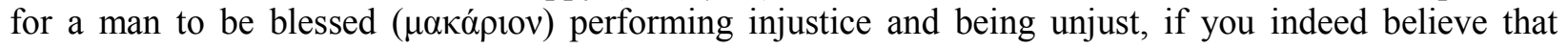

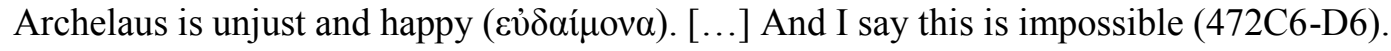


At 468E5, where Penner and Segvic conclude their interpretations, it was still unclear just what rhetoricians and tyrants wanted in their killing, confiscating, and banishing, and why exactly Socrates thought that they almost never attained it. By now, however, it is clear that it is for the sake of happiness that they do these things, and that Socrates holds that tyrants and rhetoricians performing these actions fail to achieve this end because they go about doing these things unjustly. ${ }^{27}$

Penner interpreted the difference between 'doing what one wants' and 'doing what seems best to one' as a distinction between, respectively, acting in accordance with a correctly envisaged scheme of means and ends that leads to one's desired end and an incorrectly envisaged scheme that fails of this objective. For Penner, what one wants is, primarily, the ultimate end for the sake of which one acts (i.e., the best, or most beneficial, end available in the circumstances in question), and, secondarily, the means (or series of means and ends) that lead to that ultimately desired end-but one only desires the means on condition that it in fact leads to the envisioned end, otherwise, in acting on this means, one only does what seems best to one. ${ }^{28}$ Penner's mistake consists in taking the instrumental model of desire (468A5-B4) -which is used merely as part of an argument that establishes, in one type of case, a conceptual distinction between 'doing what one wants' and 'doing what seems best to one' - to be a complete argument for Socrates' position that rhetoricians and tyrants do almost nothing they want. Penner's position thus involves an unnecessary interpretive leap from a claim that we pursue intermediate actions (like killing, confiscating, and banishing) for the sake of good ends (see 468B4-6), to a much

${ }^{27}$ David Wolfsdorf has also defended Socrates' argument for the distinction between 'doing what one wants' and 'doing what seems best to one.' He interprets the distinction between the two notions as follows: "if someone performs an action, thinking that it is beneficial, yet it is harmful, he does what he thinks best (that is, he acts according to his - in this case false- belief about how his action will achieve his terminal desire), but he does not do what he terminally desires (that is, he does not satisfy his terminal desire) (Wolfsdorf, "Rhetoric," 132). Wolfsdorf provides an incisive analysis of Socrates' argument for a distinction between 'doing what one wants' and 'doing what seems best to one' in 467B1-468E5. Furthermore, he avoids the use of technical notions that are nowhere attested in the text. But his interpretation, like those of Segvic and Penner, overestimates what this stage of argumentation accomplishes. The argument that Wolfsdorf analyzes only establishes that one can fail to do what one wants in case the intermediate action one undertakes fails of the good end for which it was undertaken. Therefore, this argument (i.e., 467B1-468E5) does not, as Segvic, Penner, and Wolfsdorf assume, fully elucidate the notion of 'doing what one wants' because we nowhere learn about the contents of (what Wolfsdorf has called) 'terminal desire,' nor do we learn why tyrants and rhetoricians in particular fail to do what they want.

${ }^{28}$ See Penner, "Desire," 182-4. 
stronger claim that in every instance of desire, we want to act in accordance with a correctly envisaged scheme of means and ends that culminates with one's ultimate desire.

We can avoid making this leap by recognizing that Socrates' argument does not conclude at 468E5. In the larger context, it becomes clear that happiness is what tyrants and rhetoricians want and that they do not do what they want because their characteristic injustice renders them unable to realize the happiness they desire (i.e., they lack the capacity to recognize when a given action is best for the soul-see 464D1-3). By reading 466A4-468E5 in light of the larger context, we are therefore able to avoid the instrumentalist account of action that Penner's interpretation involves. To anticipate the picture I spell out below: for Socrates, one does what one wants if the action that one performs represents what here and now, in these circumstances, amounts to happiness. A given action might amount to a fragment of happiness because it is conducive to happiness (i.e., one might desire the action instrumentally). But an action might likewise amount to a fragment of happiness because, in these circumstances, happiness consists in this action being performed (i.e., one might desire the action in its own right).

Segvic suggested that the distinction between 'doing what one wants' and 'doing what seems best to one' was a distinction between acting in accordance with one's opinion and one's knowledge respectively. There is indeed good reason for assuming that 'doing what seems best to one' is a matter of acting in accordance with one's opinion, a fact suggested by the etymology of the words Socrates uses: form of $\delta o ́ \xi \alpha$, "opinion." 29 However, in the passage that Segvic analyzes (sc. 466A4-468E5) there is no textual evidence that by 'doing what one wants' Socrates means acting in accordance with one's knowledge in the highly technical way that Segvic construes it. ${ }^{30}$ In fact, the only place in 466A4-468E5 where Socrates explicitly mentions knowledge, or rather intelligence (võ̃ $\varsigma$ ), is at 466E13-467A6, where Socrates defeats Polus' objection (that doing what seems best to one is sufficient for having great power) by showing that doing what seems best to one will only turn out well for one who has intelligence. But Socrates' use of the notion of knowledge in this argument (sc. 466D6-467A6) is not a matter of his contrasting 'doing what one wants' with 'doing what seems best to one'-here all he does is show that doing what seems best to one without knowledge does not count as great power. Socrates does not begin his discussion of

\footnotetext{
${ }^{29}$ See Segvic, "Intellectualism," 7.

${ }^{30}$ See Segvic, "Intellectualism," 11.
} 
wanting until 467A7, after which point the notion of knowledge does not feature in Socrates' ensuing argument for a distinction between 'doing what one wants' and 'doing what seems best to one' (467B1-466E5).

Of course, I do think that knowledge is a crucial element in the distinction between 'doing what one wants' and 'doing what seems best to one.' My contention is simply that one does not arrive at a correct understanding of the way knowledge features in this distinction by reading 466A4-468E5 in isolation, as Segvic does. Only by reading this passage in light of the larger context do we learn what desired thing tyrants and rhetoricians fail to attain (i.e., happiness - see 470C9-D3), and why they fail to attain it (i.e., they kill, confiscate, and banish unjustly, that is, without knowledge of what is best for the soul-see 470C1-3; 464C3-5).

With a more complete picture of the argument now before us, we may summarize Polus' and Socrates' positions as follows. Polus assumes that rhetoricians' and tyrants' ability to do whatever seems best to them (characteristically exhibited in their killing, confiscating, and banishing) is sufficient for their having great power and that their possession of this "power" is sufficient for their happiness (see 466E3; 470A9-12). Hence, he assumes that one can know with no further investigation that a person like Archelaus, or the Great King, is happy simply by their reputation for having power, with no consideration of how they stand in relation to justice (470D5-E5). For Polus, "power" (i.e., being able to do what seems best to one) is good all on its own and is constitutive of happiness regardless of the kind of person who possesses it. Socrates, however, thinks that rhetoricians and tyrants have exceedingly little power in their cities because they do almost nothing of the things they want; that is to say, they do not realize the happiness they desire because they kill, confiscate, and banish unjustly. This position is, yet again, informed by Socrates' conception of rhetoric as a form of flattery that merely imitates justice: rhetoricians lack the art of justice, and therefore they do not know how to apply their "power" (i.e., their ability to do what seems best to them) in a way that brings about what is best for the soul (see 464B2-466A3). For Socrates, a person is not happy (i.e., does not do what he wants) unless he is just; thus, when Polus exclaims that Socrates wouldn't even claim to know that the Great King is happy, Socrates agrees that he cannot know this simply by his reputation for power because he doesn't know "how he stands in regard to education and justice" (470E6-7).

A final note on terminology: Socrates has, in various places throughout his argument, used plural language to refer to various objects of desire (e.g., when he denies that rhetoricians 
do the things they want-see 466D8-E1; 467A8-10). How are we to reconcile this plural language with the fact that Socrates and Polus both identify a single thing - happiness - as the end that one desires when one performs intermediate actions? The idea must be something like the following: happiness - which is, strictly, a universal - is the end desired in all action, but in each particular action, what one wants is to arrive at a fragment of happiness. ${ }^{31}$ What one ultimately wants is one's overall happiness - for one's life to be a happy life-but what one wants on each occasion is to realize what here and now, in these circumstances, amounts to happiness. $^{32}$

Although happiness is one, the actions that amount to happiness are many and various (see 466D8-E1; 467A8-10). This is because many of the actions that people ordinarily perform (such as sitting, walking, running, sailing-or, in the case of tyrants and rhetoricians, killing, confiscating, and banishing, (see 467E6-468B6)) are intermediate, and only in fact turn out well when they are properly performed in the appropriate circumstances (see 470A12-B4; 470C1-3). Whether or not a given action is appropriate depends upon the situation, and only a person with the relevant virtue, or art-understood as a capacity for getting things right with respect to some domain (see 464C4-465A7) - is able reliably to recognize when the action in question is appropriate.

Socrates and Polus agree that intermediate actions aim to achieve the same universal

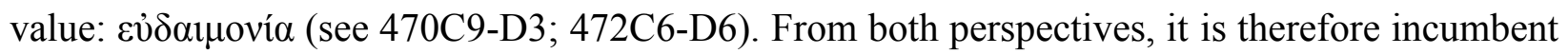
upon the agents who face a situations that present them with various intermediate actions to determine which action, of those available, would best contribute to their happiness. For Socrates, the virtue relevant for correctly reading situations that involve intermediate actions such as killing, confiscating, and banishing is justice, and moreover, instances of killing, confiscating, and banishing only amount to happiness when someone who is just performs them (470B1-C3). Thus, with respect to the intermediate actions that, for Polus, characterize the great power of rhetoricians and tyrants, it is only the just who are able reliably to see when and how

${ }^{31}$ In trying to understand this picture I have benefitted from John McDowell's treatment of Aristotelian ethics (see McDowell, John. "Virtue and Reason" ["Virtue"], The Monist, 62.3 (1979), 331-350; see also McDowell, John. "Deliberation and Moral Development in Aristotle's Ethics" ["Deliberation"], in S. Engstrom and J. Whiting, Aristotle, Kant, and the Stoics: Rethinking Happiness and Duty (Cambridge, 1996), 19-35).

${ }^{32}$ See McDowell, "Deliberation,” 20-21. 
these actions ought to be performed, that is, only they are able to recognize when performing such an action constitutes, in these circumstances, a case of doing what they want.

For Socrates only the just life is a happy life because only practitioners of justice possess the relevant knowledge of what is best for the soul (see 465A3-4). A practitioner of justice knows what, in each case, is best for the soul and this knowledge constitutes a capacity to read situations to see when performing a given action would amount to doing what one wants. However, rhetoricians and tyrants do not realize happiness (i.e., do not do what they want) when they kill, confiscate, or banish because they lack the art of justice (i.e., they lack the knowledge of what is best for the soul). Unjust tyrants or rhetoricians therefore only do what seems best to them because they lack the capacity to recognize when killing, confiscating, or banishing would count as an instance of doing what they want.

\section{Conclusion}

The aim of this study has been to show that Socrates' argument that tyrants and rhetoricians have the least power in the city is not only tenable, but that there is also no need to posit technical usages of the words 'power' and 'want' to make sense of Socrates' arguments. I have tried to show this by first providing my own interpretation of the first and second formulations of Socrates' argument, defending them against apparent weaknesses, and by then analyzing the subsequent dialectical context in which I take Socrates to complete his explanation of his position.

In part 2 I defended Socrates' first stage of argumentation in which he undermines Polus' assumption that the ability to do what seems best to one is sufficient for having great power (466A4-467A10). In this exchange, Socrates does not arbitrarily restrict his use of 'power', but rather, confirms Polus' quite conventional belief that power is a good thing in an unqualified sense and then qualifies this belief by showing that power is only actually good when it is accompanied by intellect and wielded by art (466E13-467A6). Socrates' argument leaves Polus with the burden of proof to show that rhetoricians have intelligence: otherwise, in doing what seems best to them, rhetoricians do not exercise power that is good for the one who has it. Socrates' argument against Polus' assumption thus turned out simply to be a reinforcement of the 
position that he had already taken against rhetoric as a form of flattery in an earlier passage (464B2-466A3).

In part 3 I discussed Socrates' second stage of argumentation in which he argues for a distinction between 'doing what one wants' and 'doing what seems best to one' (476B1-468E5). I first showed that the alleged equivocations Socrates makes over his use of 'want' are not necessarily warranted by the text. I then appealed to the fact that, at the conclusion of Socrates' argument for this distinction, Socrates has not yet provided a full account of his position. All that Socrates has shown at 468E5 is that it is possible for someone doing what seems best to one to not be doing what one wants in case the intermediate things one does for the sake of good things turn out badly. At this point, where Segvic and Penner both conclude their interpretations, we still have yet to learn what it is that tyrants and rhetoricians want out of their killing, confiscating, and banishing, and we also have yet to learn why they fail to achieve this end.

The passage which I then discussed in part 4 reveals that both Polus and Socrates think

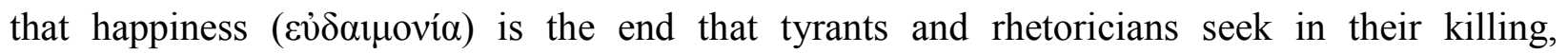
confiscating, and banishing, and that Socrates thinks that they fail to achieve this end because they do these things unjustly. This was then simply a recapitulation of Socrates' earlier claim that rhetoric is not an art, framed in terms of the rhetorician's failure to get what he wants. It is therefore because of their injustice that rhetoricians, like the tyrants they emulate, fall short of the happy life that they want. Although they are able to do whatever seems best to them, they do none of the things they want.

Ian J. Campbell Princeton University 


\section{References}

Dodds, E. R., Plato's Gorgias: A Revised Text with Introduction and Commentary [Gorgias] (Clarendon, 1959).

McDowell, John. "Virtue and Reason" ["Virtue"], The Monist, 62.3 (1979), 331-350.

McDowell, John. "Deliberation and Moral Development in Aristotle's Ethics" ["Deliberation"] in Stephen Engstrom and Jennifer Whiting, Aristotle, Kant, and the Stoics: Rethinking Happiness and Duty (Cambridge, 1996), 19-35.

McTighe, Kevin. "Desire for the Good and the Involuntariness of Wrongdoing: Gorgias 466a-468e" [“Desire"], Phronesis, 29.3 (1984), 193-236.

Olympiodorus. Commenary on Plato's Gorgias, trans. Robin Jackson, Kimon Lycos, and Harold Tarrant (Leiden, 1998).

Penner, Terry. "Desire and Power in Socrates: The Argument of Gorgias 466A-468E that Orators and Tyrants Have No Power in the City" ["Desire"], Apeiron. 24 (3), 147-202.

Penner, Terry and C.J. Rowe. "The Desire for Good: Is the Meno inconsistent with the Gorgias?" ["Meno"], Phronesis, 39.1 (1994), 1-25.

Segvic, Heda. "No One Errs Willingly: The Meaning of Socratic Intellectualism" ["Intellectualism"], Oxford Studies in Ancient Philosophy, 19 (2000), 1-40.

Vlastos, Gregory. "Does Socrates Cheat?" in G. Vlastos, Socrates: Ironist and Moral Philosopher (Cornell, 1991), 132-156.

Weiss, Roslyn. "Ignorance, Involuntariness, and Innocence: A Reply to McTighe," Phronesis, 30.3 (1985), 314-322.

Weiss, Roslyn. "Killing, Confiscating, and Banishing at Gorgias 466-468" ["Killing"], Ancient Philosophy, 12.2 (1992), 299-315.

Wolfsdorf, David. “Gorgias 466a4-468e5: Rhetoric's Inadequate Means" [“Gorgias"], Classical Philology, 103.2 (2008), 109-34. 